\title{
Human atrial natriuretic peptide infusion and ovarian venous progesterone secretion in Yucatan micropigs
}

\author{
A. I. Musah, J. F. Bloch, S. L. Baker and G. D. Schrank \\ Department of Biological Sciences, College of Science and Technology, St Cloud State University, \\ St Cloud, MN 56301-4498, USA
}

\begin{abstract}
Chronic indwelling catheters were implanted in the ovarian and external jugular veins of Yucatan micropigs during the luteal phase. Infusion of hypertonic saline $\left(0.4 \mathrm{~mol} \mathrm{NaCl} \mathrm{l}^{-1}\right)$ increased the concentration of porcine immunoreactive atrial natriuretic peptide in ovarian venous blood plasma by $0.61-1.81 \mathrm{fmol} \mathrm{ml}^{-1}$ more than that of the saline control group. Conversely, endogenously released porcine immunoreactive atrial natriuretic peptide was associated with low ovarian venous progesterone concentrations. Infusion of human atrial natriuretic peptide induced a dose-dependent increase in the progesterone concentration in ovarian venous blood. The results reported here suggest a duality in the ovarian response to atrial natriuretic peptide: a decrease in progesterone secretion in response to low concentrations and stimulated progesterone secretion in response to high concentrations of this peptide.
\end{abstract}

Introduction

Atrial natriuretic peptides (ANPs) are a family of peptides that were first discovered in cardiac myocytes (de Bold et al., 1981; Flynn et al., 1983; de Bold, 1985). The ANP family primarily inhibits renal tubular reabsorption of $\mathrm{Na}^{+}$(Samson, 1992) and thus is important in fluid and electrolyte balance (Cantin and Genest, 1985), including natriuresis, kaliuresis, diuresis and vasodilation (Geller et al., 1984). ANP decreases blood pressure, and vasoconstriction induced by angiotensin, adrenaline and $\mathrm{K}^{+}$(Samson, 1992). Extra-cardiac sources of ANP include the hypothalamus (Kawata et al., 1985; Samson et al., 1988, 1993), the pituitary (Kawata et al., 1985) and the ovarian tissue of pigs (Kim et al., 1989), cows (Vollmar et al, 1988; Brunswig et al., 1989), humans (Pandey et al., 1987; Steegers ef al., 1990), rats (Zhao et al., 1991; Kim et al., 1992; Gutkowska et al., 1993) and rabbits (Kim et al., 1989). In addition to its role in regulating fluid and electrolyte balance, ANP also modulates steroidogenesis. Racz et al. (1985) reported that ANP inhibits the secretion of aldosterone, deoxycorticosterone and progesterone from cultured bovine zona glomerulosa and cortisol, and of corticosterone and progesterone from fasciculata cells Human follicular fluid contains ANP (Steegers ef al,, 1990), which could be important as an intragonadal regulator of ovarian function.

The objective of this study was to evaluate the effects of human ANP (hANP) and hypertonic saline infusion on ovarian progesterone secretion in Yucatan micropigs.
Materials and Methods

Animals and surgical procedures

Four-month-old Yucatan micropigs were purchased (Charles River Labs, Wilmington, MA) and maintained in a controlled environment. They were hand-fed $0.25 \mathrm{~kg}$ of a maintenance diet (Minipig Breeder No. 5082, Purina Mills, St Louis, MO) twice a day. Water was provided ad libitum. At 15 months of age, oestrus was synchronized by oral administration of altrenogest $(0.22 \%$ oral progestin solution: $17 \alpha$-allyl-17 $\beta$ hydroxyestra-4,9,11-tien-3-one; Roussel-UCLAF, Paris) at a rate of $10.10 \mathrm{mg} \mathrm{day}^{-1}$ for 14 days. (The day when altrenogest treatment began was day 1 .)

On days 17 and 18 , after $24 \mathrm{~h}$ presurgical fasting, chronic indwelling catheters were implanted in the external jugular vein and in one ovarian vein using anaesthetic and laparoscopic techniques described by Musah et al. (1984). At the bifurcation of the utero-ovarian vein into the ovarian and uterine veins, a 15-gauge stainless steel hypodermic needle (Popper and Son Inc, New Hyde Park, NJ) was inserted into the ovarian vein about $1.0 \mathrm{~cm}$ from the point of the bifurcation in the direction of the ovary. Intramedic polyethylene tubing $(0.575 \mathrm{~mm}$ i.d. $0.95 \mathrm{~mm}$ o.d.; Becton, Dickinson and Co, Parsippany, NJ) was threaded through the needle into the vein. Silk thread knots were used to fasten the vessel around the catheter and to attach the catheter to the broad ligaments. The catheter was exteriorized through the midventral incision and tunnelled underneath the skin of the flank region. The external portions of the catheter were enclosed in a pouch attached to the dorsolateral flank. 
Chronic indwelling external jugular vein catheterizations were performed through a $6-8 \mathrm{~cm}$ ventral incision made about $4 \mathrm{~cm}$ lateral to the midline from the point of the mandible to the point of the shoulder. The skin and fascia were exposed and the external jugular vein located. The vein was dissected free of fascia for $5 \mathrm{~cm}$ along its length. Tygon microbore tubing (1.25 mm i.d., $2.25 \mathrm{~mm}$ o.d.; Nurton Plastic, Akron, $\mathrm{OH}$ ) was inserted into the vein and held in place by two knots around the posterior and anterior ends of the tubing. The catheter was tunnelled subcutaneously to the dorsum of the neck and exteriorized. The external portion of the indwelling catheter was stored in a pouch on the dorsum of the neck.

\section{Treatments}

From day 10-12 after ovulation (peak luteal phase), micropigs were infused (Orion Sage Syringe Pump No. 355, Orion Research Inc, Boston, MA) at a rate of $1.0 \mathrm{ml} \mathrm{min}{ }^{-1}$ for $10 \mathrm{~min}$ with saline or different doses of hANP (Sigma Chemical $\mathrm{Co}$, St Louis, MO). The study consisted of seven treatment groups: control saline $\left(0.15 \mathrm{~mol} \mathrm{NaCl} l^{-1}\right)$, hypertonic saline $\left(0.4 \mathrm{~mol} \mathrm{NaCl} \mathrm{l}^{-1}\right), 0.16,0.32,0.81,1.6$ and $2.4 \mathrm{nmol}$ hANP $1^{-1}$. The micropigs were randomly assigned to treatments and treatment performed in rotation until all animals had received all treatments (four pigs for each treatment). At intervals of $10 \mathrm{~min}$ from $10 \mathrm{~min}$ before the start of a particular treatment to $60 \mathrm{~min}$ afterwards, $2-3 \mathrm{ml}$ of ovarian venous blood was obtained and transferred into cryovials containing $10 \mathrm{U}$ of sodium heparin. Catheters were kept patent during and after experiments by periodically flushing with heparinized saline. Plasma from blood samples was stored at $-70^{\circ} \mathrm{C}$.

\section{Assay procedures}

Porcine immunoreactive ANP (Ir-pANP) concentration was determined using a heterologous assay based upon a human ANP radioimmunoassay kit (Code RPA 512, Batch No. B48A, Amersham International, Amersham, Bucks). Ir-pANP was extracted from plasma using C-8 columns, and assay tubes containing an assay buffer of $0.025 \mathrm{~mol}$ phosphate buffer $1^{-1}$ $(\mathrm{pH} 7.2)$ and sodium azide $(1 \%, \mathrm{w} / \mathrm{v})$ were incubated with $100 \mu \mathrm{l}$ of rabbit anti- $\alpha$ ANP serum at $2-8^{\circ} \mathrm{C}$ for $16-24 \mathrm{~h}$. After $24 \mathrm{~h}, 100 \mu \mathrm{l}$ of ${ }^{125} \mathrm{I}$-labelled $\alpha \mathrm{ANP}$ was added to all tubes and incubated for another $24 \mathrm{~h}$ at $2-8^{\circ} \mathrm{C}$. Antibody-ANP complex was separated from free ANP by the Amerlex-M system (Amersham International). Nonspecific binding for the heterologous assay was $4.2 \%$ and the sensitivity was $26 \mathrm{pg} \mathrm{ml}^{-1}$.

Progesterone in ovarian venous blood was quantified using an RSL ${ }^{125}$ I Progesterone Kit (ICN Biomedicals Inc, Irvine, CA). The maximum binding of the assay was $43.4 \%$ and nonspecific binding was $4.8 \%$. The standard curve was from 0.2 to $50 \mathrm{ng} \mathrm{ml}^{-1}$. Antiserum was generated in rabbits using $11 \alpha-$ hydroxyprogesterone-11 $\alpha$-hemisuccinate-human serum albumin. The antibody-bound antigen complex was precipitated with a solution of goat anti-rabbit $\gamma$ globulins and polyethylene glycol. The assay buffer was made of phosphate-buffered saline, $\mathrm{pH} 7.6$, containing rabbit $\gamma$ globulins and $0.1 \%$ sodium azide.

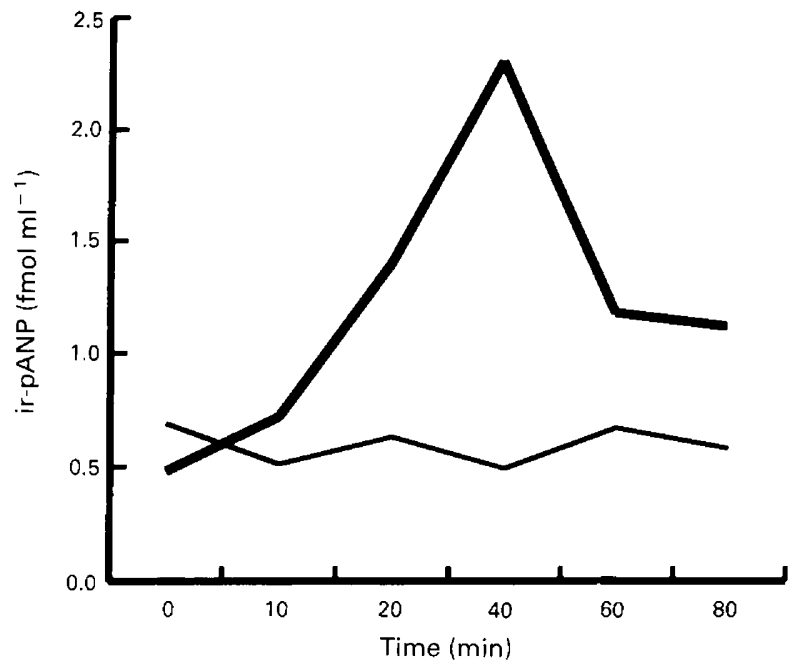

Fig. 1. Effects of jugular vein infusion $\left(1 \mathrm{ml} \mathrm{min}^{-1}\right.$ for $\left.10 \mathrm{~min}\right)$ of control $\left(0.15 \mathrm{~mol} \mathrm{NaCl} \mathrm{I}{ }^{-1}\right.$ physiological saline; thin line) and hypertonic saline $\left(0.4 \mathrm{~mol} \mathrm{NaCl}^{-1}\right.$; thick line) on the concentration of porcine immunoreactive atrial natriuretic peptide (ir-pANP) in ovarian venous blood plasma of Yucatan micropigs. Pooled SE is 0.19.

\section{Statistical analysis}

The experimental design was a partially balanced incomplete block design arranged in a latin square formation (Youden squares, Cochran and Cox, 1957). Yucatan micropigs ( $n=4)$ represented rows (replicates) and the blocks were represented by the treatments $(n=7)$. The micropigs were randomly assigned to treatments until all animals received all treatments. The data were analysed by treatment and effects of time using, where appropriate, analysis of variance, general linear model analysis and Student's $t$ test (Snedecor and Cochran, 1967) with PC-SAS (release 6.01, SAS Institute, Raleigh, NC).

\section{Results}

Yucatan micropigs to which altrenogest ( $10.10 \mathrm{mg}^{\text {day }}{ }^{-1}$ for 14 days) had been orally administered exhibited behavioural oestrus $5.6 \pm 0.4$ days after altrenogest withdrawal. Hypertonic saline $\left(0.4 \mathrm{~mol} \mathrm{NaCl} \mathrm{l^{-1 }}\right)$ infusion increased the ir-pANP concentration from 0.49 to $0.69 \mathrm{fmol} \mathrm{ml}^{-1}$ in the physiological saline control group and from 1.1 to $2.5 \mathrm{fmol} \mathrm{ml}^{-1}$ for the hypertonic saline group (Fig. 1). The mean deviation of ovarian venous blood progesterone concentrations (mean deviations from pretreatment means) were significantly depressed 10-60 min after commencement of hypertonic saline infusion (Table 1).

Human ANP administered at 0.16, 0.32, 0.81, 1.6 and $2.4 \mathrm{nmol} \mathrm{ml}{ }^{-1} \mathrm{~min}^{-1}$ was associated with significant changes in ovarian venous progesterone concentrations. Low doses of hANP $\left(0.16,0.35\right.$ and $\left.0.81 \mathrm{nmol} \mathrm{ml}{ }^{-1} \mathrm{~min}^{-1}\right)$ were associated with a dose-dependent increase $(P<0.5)$ in ovarian venous blood plasma progesterone concentration between 10 and 20 min after onset of infusion (Fig. 2). After an initial high secretion of progesterone, there was a subsequent decrease $(P<0.05)$ in progesterone concentration between 40 and Downloaded from Bioscientifica.com at 04/26/2023 06:50:18AM 
Table 1. Progesterone concentrations ( $\mathrm{nmol} \mathrm{ml}{ }^{-1}$ ) in ovarian venous blood in Yucatan micropigs after infusion of physiological and hypertonic saline

\begin{tabular}{|c|c|c|c|c|c|c|}
\hline \multirow[b]{2}{*}{ Experimental group } & \multicolumn{6}{|c|}{ Time (min) after start of infusion } \\
\hline & 0 & 10 & 20 & 40 & 60 & 80 \\
\hline $\begin{array}{l}\text { Physiological saline } \\
\left(0.15 \mathrm{~mol} \mathrm{NaCl}^{-1}\right)\end{array}$ & 0.00 & 0.01 & 0.04 & 0.06 & 0.04 & 0.03 \\
\hline $\begin{array}{l}\text { Hypertonic saline } \\
\qquad\left(0.4 \mathrm{~mol} \mathrm{NaCl} 1^{-1}\right)\end{array}$ & 0.00 & $-0.13^{*}$ & $-0.24^{*}$ & $-0.21^{*}$ & $-0.39^{*}$ & -0.03 \\
\hline
\end{tabular}

Values are means from pretreatment means.

*Values between treatments are significantly different $(P<0.05)$.

Pooled SE is 0.05

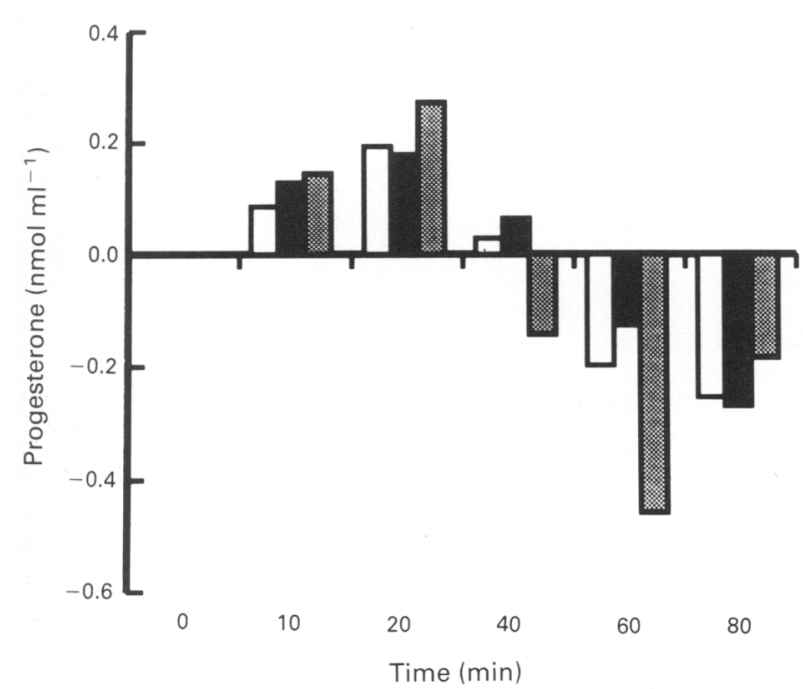

Fig. 2. Effects of jugular vein infusion ( $1 \mathrm{ml} \mathrm{min}^{-1}$ for $10 \mathrm{~min}$ ) of low doses of human atrial natriuretic peptide (hANP) $(\square, 0.16 ; \square, 0.32$; and $0.81 \mathrm{nmol} \mathrm{ml}^{-1}$ ) on ovarian venous blood plasma progesterone concentrations of Yucatan micropigs. Pooled SE is 0.004 .

$60 \mathrm{~min}$ (Fig. 2). The decrease was dose dependent, reaching a maximum depression $60 \mathrm{~min}$ after the start of infusion.

Infusion of high doses of hANP (1.6 and $2.4 \mathrm{nmol} \mathrm{ml}{ }^{-1}$ $\left.\min ^{-1}\right)$ induced a dose-dependent increase $(P<0.05)$ in the progesterone concentration in ovarian venous blood (Fig. 3). Peak concentration of progesterone occurred within $10 \mathrm{~min}$ after termination of infusion. There was no subsequent decrease in the concentration of progesterone during the blood sampling period. Progesterone concentrations were 0.08, 0.13, $0.14,0.28$ and 0.32 (pooled SE, 0.004) $10 \mathrm{~min}$ after treatment and $-0.20,-0.13,-0.46,0.46$ and 0.37 (pooled SE, 0.004) $60 \mathrm{~min}$ after treatment for $0.16,0.32,0.81,1.6$ and $2.4 \mathrm{nmol}$ $\mathrm{ml}^{-1} \min ^{-1}$ hANP, respectively.

\section{Discussion}

The regulation of ovarian cyclicity and reproductive function, and the regulation of electrolyte balance (and, as a result, blood chemistry and pressure) are not normally considered to be

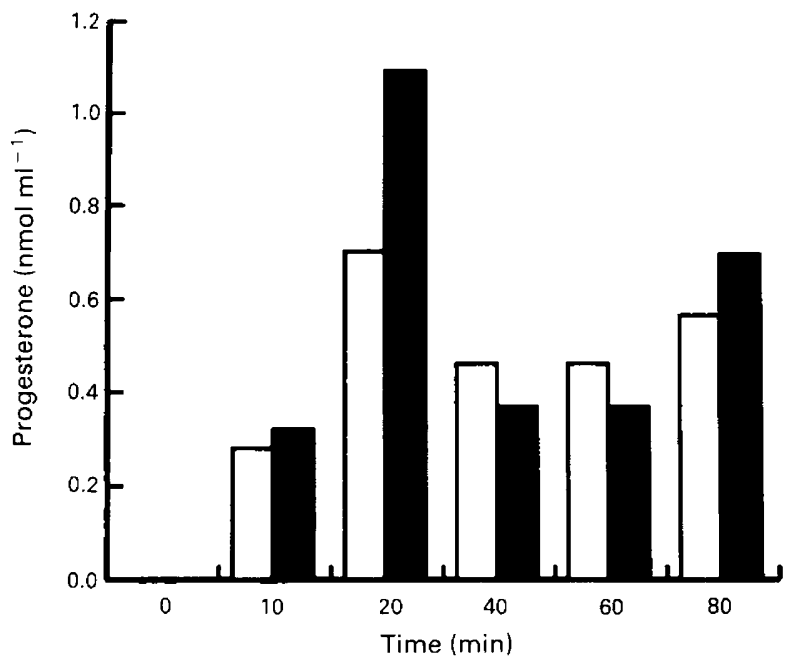

Fig. 3. Effects of jugular vein infusion ( $1 \mathrm{ml} \mathrm{min}{ }^{-1}$ for $10 \mathrm{~min}$ ) of high doses of human atrial natriuretic peptide (hANP) ( $\square, 1.6$; and $\square$, $2.4 \mathrm{nmol} \mathrm{ml} \mathrm{m}^{-1}$ ) on ovarian venous blood plasma progesterone concentrations of Yucatan micropigs. Pooled SE is 0.004 .

hormonally linked. The results reported here suggest that endogenous concentrations of ANP suppress progesterone secretion, whereas exogenous values stimulate progesterone secretion, indicating a link between reproductive function and the regulation of blood plasma volume and electrolytes. Exogenously administered hANP also induced a dosedependent increase in ovarian venous blood progesterone concentrations. However, stimulation of endogenous release of ir-pANP was associated with a decrease in progesterone concentration of ovarian veins.

Changes in ovarian steroid production after exogenous administration of ANP could be attributed to an alteration in blood flow and volume, since ANP is involved in the regulation of blood pressure and blood volume (Geller et al., 1984; Cantin and Genest, 1986; Needleman and Greenwald, 1986). However, the anatomy and physiology of the luteal vasculature must also be considered. As a muscle relaxer, ANP acts exclusively on vascular smooth muscle and not the endothelium to cause vasodilation (Cantin and Genest, 1986). Luteal vasculature consists of sinusoidal capillaries (Dharmarajan et al., 1985) that are devoid of autonomic nerves (Unsicker, 1974) Downloaded from Bioscientifica.com at 04/26/2023 06:50:18AM 
and that lack smooth muscle in rats, rabbits and monkeys (Osvaldo-Decima, 1970; Wiltbank, 1987). The corpus luteum operates on a line (maximally vasodilated) pressure curve and does not actively regulate intratissue blood flow, and is subject to acute regulation of perfusion only through changes in extraluteal vessels (Wiltbank et al., 1990).

Analysis of the concentration of progesterone, luteal blood flow and mean arterial pressure indicates that although there is no correlation between serum progesterone concentrations and luteal blood flow, there is a significant correlation between luteal blood flow and mean arterial pressure (Bruce et al., 1980; Bruce and Meyer, 1981; Wiltbank et al., 1988). However, functional demise of the corpus luteum precedes a decline in luteal blood flow (Damber et al., 1981). Acute changes in steroidogenesis and administration of exogenous hormones do not perturb luteal blood flow (Pang and Behrman, 1981; Wiltbank et al., 1989), suggesting that a sustained increase in blood pressure or volume induced by ANP may not alter steroidogenesis. Any changes in luteal steroidogenesis associated with ANP may be mediated by mechanisms other than plasma volume changes.

These findings and results of previous studies suggest that factors involved in regulating fluid and electrolyte balance may have a very profound effect on ovarian steroidogenic function. The presence of ANP in ovarian (Vollmer et al., 1988; Kim et al., 1989; Gutkowska et al., 1993) hypophysial and hypothalamic tissues (Kawata et al., 1985) indicate the possibility of separate endocrine and paracrine modes for ANP-mediated steroidogenesis in ovarian tissue. It has been suggested that an ovarian-endothelin-renin-angiotensin-ANP system is involved in a paracrine regulation of ovarian steroid production and function (Usuki et al., 1992). A separate but related endocrine effect of ANP could occur at the ovarian, pituitary and hypothalamic levels.

ANP either stimulates or inhibits steroid secretion. Aldosterone, deoxycorticosterone and progesterone secretion in the zona fasciculata is inhibited (Racz et al., 1985). In Leydig tumour cells, ANP inhibits gonadotrophin-stimulated progesterone synthesis in a similar way (Pandey et al., 1985). These inhibitory phenomena are similar to those seen in this study in which endogenously released ir-pANP decreased progesterone secretion. However, the 3-4-fold increase in progesterone secretion by cultured human granulosa cells (Pandey et al., 1987) or the dose-dependent increase in progesterone secretion by rat luteal and granulosa cells (Zhao et al., 1991) exposed to ANP can be compared to the effects of exogenously administered hANP in this study.

These results imply a duality in ovarian response to ANP - a decrease in progesterone secretion in response to low concentrations of ANP and stimulated progesterone secretion in response to high concentrations of ANP. The hypothesis of this study is that hypertonic saline induces the endocrine release of ANP from cardiac sources and paracrine release of ANP from extra-cardiac sources (such as ovarian, hypophysial and hypothalamic sites), while exogenously administered ANP may act at the endocrine level. The low paracrine concentrations of ANP would tend to suppress progesterone secretion, while endocrine release acting via other pathways stimulates progesterone secretion. ANP at the hypothalamic level typically inhibits LH release (Huang and Samson, 1991) through C-type natriuretic peptide (CNP) (Huang et al., 1992). Since progesterone and sex hormones affect the expression of mRNA encoding ANP (Hong et al., 1992), there may be a feedback interaction between ovarian steroid and hypothalamic ANP. This suggests an endocrine and a paracrine mode of action of ANP involving two systems, one within the ovary and another at the hypothalamohypophysial level. Further studies are needed to determine whether cardiac and ovarian ANP have different roles on ovarian steroidogenesis.

This study was presented in part at the 26th annual meeting of the Society for the Study of Reproduction (1993), Fort Collins, CO, USA. This project was funded by a St Cloud State Faculty Research Grant for 1991/92. Technical and logistics support was provided by G. Nielson (Waite Park Vet Clinic, St Cloud), E. Thrune, J. Osborn and T. Simpson (St Cloud State University), and G. Nelson (Granite City Pet Hospital, St Cloud).

\section{References}

Bruce NW and Meyer GT (1981) Ovarian blood flow and progesterone secretion in anaesthetized rats at day 16 of gestation, and the effects of haemorrhage Joumal of Reproduction and Fertility 61 419-423

Bruce NW, Meyer GT and Dimmitt SB (1980) Progesterone secretion and ovarian blood flow in the pregnant rat Joumal of Endocrinology 85 327-330

Brunswig B, Budnik LT and Mukhopadhyay AK (1989) Atrial natriuretic peptideinduced stimulation of cyclic GMP formation by isolated bovine luteal cells Journal of Reproduction and Fertility $86665-669$

Cantin M and Genest J (1985) The heart and atrial natriuretic factor Endocrine Reviews 6 107-127

Cantin M and Genest J (1986) The heart as an endocrine gland Scientific American 254 76-81

Cochran WG and Cox GM (1957) Balanced and partially balanced incomplete block design. In Experimental Designs (2nd Edn) pp 439-482. John Wiley and Sons, New York

Damber J-E, Janson PO, Axen C, Selstam G, Cederbald A and Ahren K (1981) Luteal blood flow and plasma steroids in rats with corpora lutea of different ages Acta Endocrinologica 98 99-105

de Bold AJ (1985) Atrial natriuretic factor: a hormone produced by the heart Science $230767-770$

de Bold AJ, Borenstein HB, Veress AT and Sonnenberg H (1981) A rapid and potent natriuretic response to intravenous injection of atrial myocardial extract in rats Life Sciences $\mathbf{2 8}$ 89-94

Dharmarajan AM, Bruce NW and Meyer GT (1985) Quantitative ultrastructural characteristics relating to transport between luteal cell cytoplasm and blood in the corpus luteum of the pregnant rat American Journal of Anatomy 172 $87-100$

Flynn TG, de Bold ML and de Bold AJ (1983) The amino acid sequence of an atrial peptide with potent diuretic and natriuretic properties Biochemical and Biophysical Research Communications 117 859-865

Geller DM, Currie MG, Wakitani K, Cole BR, Adams SP, Fok KF, Siegel NR, Eubanks SR, Galluppi GR and Needleman P (1984) Atriopeptins: a family of potent biologically active peptides derived from mammalian atria Biochemical and Biophysical Research Communications 120 333-338

Gutkowska J, Tremblay J, Antakly T, Meyer R, Mukaddam-Daher S and Nemer M (1993) The atrial natriuretic peptide system in rat ovaries Endocrinology 132 693-700

Hong M, Yan Q, Tao B, Boersma A, Han KK, Vantyghem MC, Racadot A and Lefebvre J (1992) Estradiol, progesterone and testosterone exposures affect the atrial natriuretic peptide gene expression in vivo in rats Biological Chemistry Hoppe-Seyler 373 213-218

Huang FLS and Samson WK (1991) An enkephalinergic mechanism for the hypothalamic effect of atrial natriuretic peptide to inhibit luteinizing hormone secretion Journal of Neuroendocrinology 3 127-132

Huang FLS, Skala KD and Samson WK (1992) Hypothalamic effects of C-type natriuretic peptide (CNP) on luteinizing hormone secretion Journal of Neuroendocrinology 4 325-330

Downloaded from Bioscientifica.com at 04/26/2023 06:50:18AM 
Kawata M, Nakao K, Morri Y, Kiso H, Yamshita H, Imura H and Sano Y (1985) Atrial natriuretic polypeptide: topographical distribution in the rat brain by radioimmunoassay and immunohistochemistry Neuroscience 16 521-546

Kim SH, Cho KW, Seul KH, Ryu H and Koh GY (1989) Presence of immunoreactive atrial natriuretic peptide in follicular fluid, ovary and ovarian perfusates Life Sciences 45 1581-1589

Kim SH, Cho KW, Hwang YH, Oh SH, Seul KH, Koh GY and Kim SJ (1992) Ovarian atrial natriuretic peptide during the rat estrous cycle Life Sciences $\mathbf{5 1}$ 1291-1299

Musah AI, Ford JJ and Anderson LL (1984) Progesterone secretion as affected by 17ß-estradiol after hysterectomy in the pig Endocrinology 115 1876-1882

Needleman P and Greenwald JE (1986) Atriopeptin: a cardiac hormone intimately involved in fluid, electrolyte, and blood-pressure homeostasis The New England Journal of Medicine 314 828-834

Osvaldo-Decima L (1970) Smooth muscle structure in the ovary of the rat and monkey Journal of Ultrastructural Research 29 218-219

Pandey KN, Kovacs WJ and Inagami T (1985) The inhibition of progesterone secretion and the regulation of cyclic nucleotides by atrial natriuretic factor in gonadotropin responsive murine Leydig tumor cells Biochemical and Biophysical Research Communications 133 800-806

Pandey KN, Osteen KG and Inagami T (1987) Specific receptor-mediated stimulation of progesterone secretion and CGMP accumulation by rat atrial natriuretic factor in cultured human granulosa-lutein $(\mathrm{G}-\mathrm{L})$ cells Endocrinology 121 1195-1197

Pang $\mathrm{CY}$ and Behrman HR (1981) Acute effects of prostaglandin $\mathrm{F}_{2 \alpha}$ on ovarian and luteal blood flow, luteal gonadotropin uptake in vivo, and gonadotropin binding in vitro Endocrinology 108 2239-2244

Racz K, Kuchel O, Cantin M and De Léan A (1985) Atrial natriuretic factor inhibits the early pathway of steroid biosynthesis in bovine adrenal cortex FEBS Letters 192 19-22

Samson WK (1992) Natriuretic peptides: a family of hormones Trends in Endocrinology and Metabolism 3 86-90
Samson WK, Aguila MC and Bianchi R (1988) Atrial natriuretic factor inhibits luteinizing hormone secretion in the rat: evidence for a hypothalamic site of action Endocrinology 122 1573-1582

Samson WK, Huang FLS and Fulton RJ (1993) C-type natriuretic peptide mediates the hypothalamic actions of the natriuretic peptides to inhibit luteinizing hormone secretion Endocrinology 132 504-509

Snedecor GW and Cochran WG (1967) Two-way classifications. In Statistical Methods (6th Edn) pp 299-310. Iowa State University Press, Ames

Steegers EAP, Hollanders JMG, Jongsma HW and Hein PR (1990) Atrial natriuretic peptide and progesterone in ovarian follicular fluid Gynecologic and Obstetric Investigation 29 185-187

Unsicker K (1974) Qualitative and quantitative studies on the innervation of the corpus luteum of rat and pig Cell and Tissue Research 152 513-523

Usuki S, Tanaka J, Kawakura Y and Usuki Y (1992) A proposal of ovarian ERAANP (endothelin-renin-angotensin-atrial natriuretic peptide system) and the effects of tokishakuyakusan American Joumal of Chinese Medicine 20 65-74

Vollmar AM, Mytzka C, Arendt RM and Schulz R (1988) Atrial natriuretic peptide in bovine corpus luteum Endocrinology 123 762-767

Wiltbank MC (1987) Regulation of Blood Flow to the Rabbit Corpus Luteum PhD Thesis, University of Michigan

Wiltbank MC, Dysko RC, Gallagher KP and Keyes PL (1988) Relationship between blood flow and steroidogenesis in the rabbit corpus luteum Journal of Reproduction and Fertility 84 213-220

Wiltbank MC, Gallagher KP, Dysko RC and Keyes PL (1989) Regulation of blood flow to the rabbit corpus luteum: effects of estradiol and human chorionic gonadotropin Endocrinology 124 605-611

Wiltbank MC, Gallagher KP, Christensen AK, Brabec RK and Keyes PL (1990) Physiological and immunocytochemical evidence for a new concept of blood flow regulation in the corpus luteum Biology of Reproduction 42 139-149

Zhao YL, Wang JH and Cheng CP (1991) Effect of ANP on estradiol and progesterone production by rat ovarian cells Sheng Li Hsueh Pao 43 580-583 